\title{
Hypoxia increases intensity of epidermal papillomatosis in roach Rutilus rutilus
}

\author{
Tiina L. Korkea-aho ${ }^{1, *}$, Janne M. Partanen${ }^{1}$, Jussi V. K. Kukkonen ${ }^{2}$, Jouni Taskinen ${ }^{3}$ \\ ${ }^{1}$ Department of Biosciences, University of Kuopio, PO Box 1627, 70211 Kuopio, Finland \\ ${ }^{2}$ Faculty of Biosciences, University of Joensuu, PO Box 111, 80101 Joensuu, Finland \\ ${ }^{3}$ Ecological Institute, Faculty of Biosciences, University of Joensuu, PO Box 111, 80101 Joensuu, Finland
}

\begin{abstract}
Hypoxia, which occurs frequently in aquatic ecosystems and is mainly due to increasing eutrophication can cause severe environmental stress in fish. We investigated experimentally the hypothesis that hypoxia could be one of the environmental stress factors that can induce papillomatosis in fish. Male roach Rutilus rutilus exposed to periodic oxygen deficiency and accompanied temperature increases (OT group) showed the highest increase in the intensity of papillomatosis, as measured by the number of scales covered by papillomatosis tumors. The second highest increase in disease intensity was among male roach exposed to periodical temperature increases. The incidence of such tumors was lowest in the control group, which was exposed to neither hypoxia nor increased temperature. The mortality of fish during the $17 \mathrm{~d}$ experiment was highest and the condition factor was lowest in the OT group, indicating this group experienced a higher level of stress. The apparent interaction of hypoxia and temperature suggests that these environmental stressors are among the multifactorial elements leading to papillomatosis in roach. Furthermore, these results provide experimental evidence to indicate that hypoxia may contribute to tumor development in fish.
\end{abstract}

KEY WORDS: Epidermal papillomatosis · Oxygen deficiency · Temperature · Environmental stress · Disease intensity · Fish

Resale or republication not permitted without written consent of the publisher

\section{INTRODUCTION}

Hypoxia occurs extensively over large areas in freshwater (Mallin et al. 2006) and marine coastal systems (Wu 2002) and the increase in hypoxia has been predominantly attributed to anthropogenic nutrient inputs and eutrophication (Wu 2002). Oxygen deficiency causes severe environmental stress for feral fish (Zhou et al. 2001, Wu et al. 2003), leading to impaired reproduction and enhanced susceptibility to diseases and mortality (Diaz \& Rosenberg 1995, Wu 2002, Wu et al. 2003).

Hypoxia can increase the infection rate and resulting mortality in fish for several fish pathogens in experimental conditions (e.g. Mqolomba \& Plumb 1992, Fisk et al. 2002). Results of field studies suggest that low oxygen concentrations may have increased the prevalence of papillomatosis in the North Sea dab Limanda limanda (Mellergaard \& Nielsen 1995, 1997). How- ever, no experimental studies exist on the effect of low oxygen on the development of papillomatosis in fish.

Epidermal papillomatosis may indicate environmental stress in fish. Natural stressors, such as salinity (Peters \& Peters 1979), temperature (Peters 1977) and crowding (Premdas \& Metcalfe 1994), have induced epidermal papillomatosis in fish. Several field studies have suggested that artificial stressors increase papilloma prevalences in polluted areas in freshwater (e.g. Premdas et al. 1995, Baumann et al. 1996, Kortet et al. 2002, Korkea-aho et al. 2006a) and marine (Vethaak et al. 1992) environments. The connection between papillomatosis and environmental stress is probably a result of both the stress-induced suppression of the immune system of fish and tumor-promoting effects of contaminants (Lee \& Whitfield 1992, Sano et al. 1993, Baumann et al. 1996). Periodic hypoxia is relatively common in shallow, eutrophic Finnish lakes dominated by cyprinids such as roach Rutilus rutilus (Lehtonen \& Rask 2004). The wide- 
spread distribution of the roach makes it a good indicator species for detection of environmental stressors by the monitoring of the roach-papillomatosis system.

In addition to environmental stress, the natural hormonal cycles could impair the immune system of fish (Pickering 1986, Watanuki et al. 2002) and thereby affect papillomatosis. Premdas et al. (2001) also showed that hormonal manipulations affect the development of papillomatosis. Papillomatosis in roach peaks during spawning in spring (Kortet et al. 2002, Vainikka et al. 2004a), a time when concentrations of the stress hormone cortisol are elevated (Vainikka et al. 2004a), sex hormone concentrations change (Kestemont et al. 1999, Kortet et al. 2003b, Vainikka et al. 2004b), and immune functions could be suppressed (Kortet et al. 2003a, Vainikka et al. 2004b). By spawning in shallow backwaters, roach are more susceptible to stressors such as solar radiation and high or variable temperature. Moreover, roach have a lek-like mating system (Wedekind 1996, Kortet et al. 2004), which might further induce stress through crowding and social interactions (e.g. Barcellos et al. 1999). All these factors can result in stress for roach in spring.

The aim of this research was to determine the effect of oxygen deficiency on the development of epidermal papillomatosis in roach. Due to the lower oxygen content of water and higher metabolic activity of fish in higher temperatures, we included temperature treatment as a variable in the oxygen deficiency experiment. In addition, we recorded the relationships between the stressors (hypoxia and temperature) and the physiological indices of the fish. The following hypotheses were tested: (1) papillomatosis development is accelerated in roach exposed periodically to both oxygen deficiency and elevated temperature, and (2) papillomatosis development is accelerated by periodic temperature increases.

\section{MATERIALS AND METHODS}

Fish and experimental protocol. The experiment was performed with the permission of the National Laboratory Animal Center, Finland (Permission No. STO222-99, 04-18). Fish were caught in fish traps from Lake Kallavesi, near the city of Kuopio on 24 March 2004. They were carefully transported to a laboratory tank supplied with flow-through lake water. The day after capture, 15 diseased roach (with visible papillomas) were transferred to each of 6 circular plastic tanks (70 1, $60 \mathrm{~cm}$ in diameter). The tanks received constant water flow from Lake Kallavesi through a drum filter (40 $\mu \mathrm{m}$ mesh size) at 2.5 to $3 \mathrm{l} \mathrm{min}^{-1}$ to a volume of $60 \mathrm{l}$. The tanks were partly shaded from above to prevent direct light into the tanks.

Fish were anesthesized with a $0.01 \%$ solution of ethyl 3-aminobenzoate methanosulfate (MS-222, Sigma) in the water at the start of experiment. The fish were marked by fin clipping for individual identification and measured for total length. The intensity of the epidermal papillomatosis was recorded by counting the number of scales that were covered by papillomas as described by Korkea-aho et al. (2006b). The fish were fed in excess with commercial feed pellets throughout the experiment. Temperature and oxygen were measured (OxyGuard ${ }^{\circledR}$ oxygen electrode) once a day, except for the periods of exposure to low oxygen when measurements were made at least 10 times per day (Fig. 1). At the end of the experiment the fish were killed with a blow to the head and immediately bled from the caudal vein with a heparinized syringe and needle. The fish were examined for the intensity of epidermal papillomatosis, weighed and measured for length and gonad mass. Three physiological indices were recorded: (1) gonadosomatic index (GSI) = [gonad weight $(\mathrm{g}) /$ fish weight $(\mathrm{g})] \times 100$; $(2)$ condition
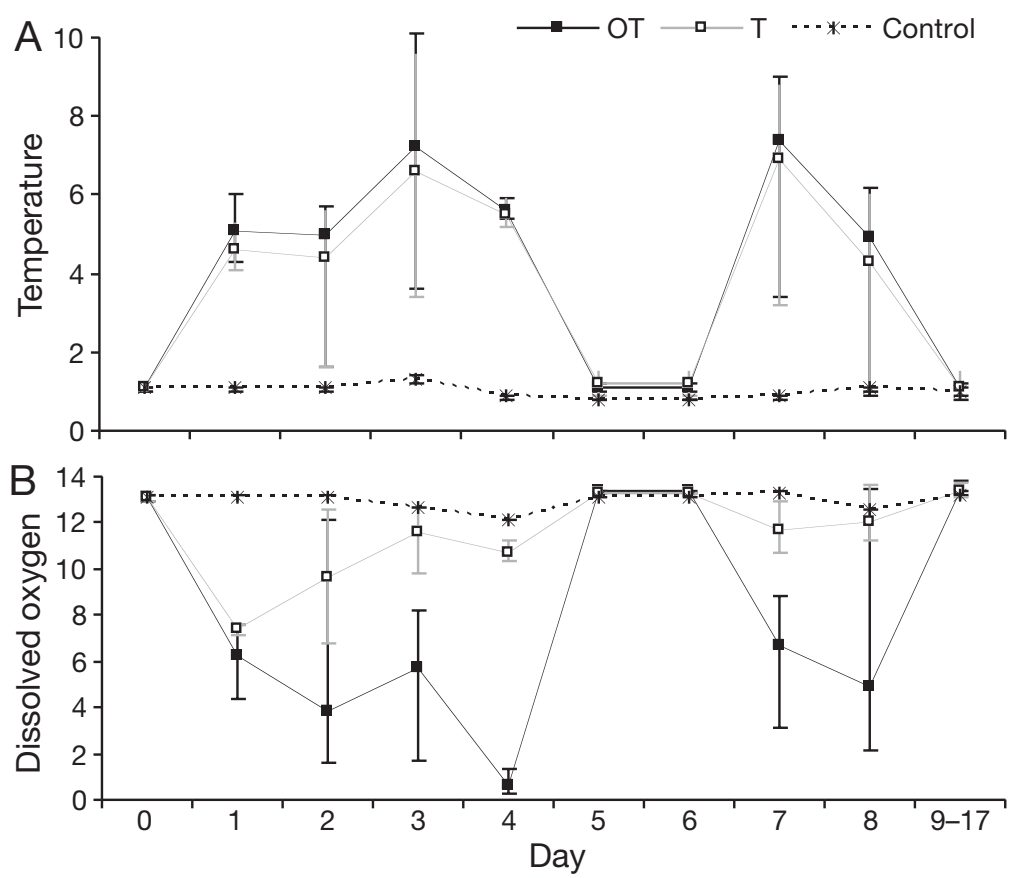

Fig. 1. (A) Mean water temperature $\left({ }^{\circ} \mathrm{C}\right)$ and (B) dissolved oxygen $\left(\mathrm{mg} \mathrm{l}^{-1}\right)$ in different Rutilus rutilus treatment groups. Bars denote daily maximum and minimum values. OT: elevated water temperature and low oxygen; $\mathrm{T}$ : normoxic, elevated water temperature (see Table 1 for a complete description of treatments) 
factor $(K)=\left[\right.$ fish weight $(\mathrm{g}) /$ fish length $\left.(\mathrm{cm})^{b}\right] \times 100$, where $b$ is the slope of a regression of lg (weight) on lg (length) of the fish included in the experiment (Bolger \& Connolly 1989); and (3) haematocrit (percentage of red blood cells in whole blood).

Three treatment groups were established. The OT group was exposed to periodic low oxygen, periodic temperature increase and periodic standing water. The $\mathrm{T}$ group experienced normoxia, but was exposed to periodic temperature increase and periodic standing water. The control group was in constant low temperature, constant water flow and normoxic conditions (Fig. 1). The temperature and dissolved oxygen regimes tested are environmentally realistic and control conditions were as non-stressful as possible. Every group included 2 replicate tanks with 15 fish each, for a total of 90 fish.

The experiment started on 29 March 2004 by stopping water flow in the OT and $\mathrm{T}$ group tanks on Day 0 (Fig. 1). Consequently, temperature started to increase and oxygen content decreased in those tanks. However, the $\mathrm{T}$ group tanks were supplied with aeration starting on Day 1, which kept the oxygen content in the $\mathrm{T}$ group at the level experienced by the control group (Fig. 1).

There were 2 treatment exposure periods, the first one lasting from Day 0 to Day 4 and the second from Day 6 to Day 8 (Fig. 1). To change the water in the tanks, water flow $\left(0.5 \mathrm{l} \mathrm{min}^{-1}\right)$ was turned on in the OT and T tanks on Day 3 for $3 \mathrm{~h}$. After water replacement, the water flows were turned off and the tanks were heated using aquarium heaters to achieve the desired temperature. In addition, OT tanks were aerated twice for 3 to 5 min during Day 4, as the dissolved oxygen content decreased to as low as 0.3 to $0.8 \mathrm{mg} \mathrm{l}^{-1}$ and some of the fish started to loose equilibrium. At the end of Day 4, the water flow was turned on in the OT and $\mathrm{T}$ tanks for $2 \mathrm{~d}$, thereby increasing the oxygen content and decreasing water temperature to the level of the control tanks. The second exposure period, from Day 6 to Day 8, was performed as described for the first period. Behavior of the fish was observed for signs of stress during both the exposure periods. The signs of stress observed included dissolution flight reaction from direct light, swimming near the water surface, increased respiratory intensity and loss of equilibrium. From Day 9 to the end of the experiment, Day 17, the conditions were the same in the OT, $\mathrm{T}$ and control tanks with regard to their oxygen content, temperature (Fig. 1) and water flow (2.5 to $31 \mathrm{~min}^{-1}$ ).

Statistical analyses. Differences in mortality of fish between the treatment groups were analyzed using $\chi^{2}$ test. All of the fish that died during the experiment and female fish $(2,5$ and 2 in OT, T and control groups, respectively) were excluded from further statistical analyses. Only male fish were included in the statistical analyses since sex affects occurrence of papillomatosis in roach (Kortet et al. 2002, Korkea-aho et al. $2006 \mathrm{~b})$, and the number of females was too small to allow for conclusive statistical analyses. One fish was also excluded because of misidentification due to failure in individual fin clip marking. Furthermore, we did not obtain blood from every fish, which lowered the number of fish used for the haematocrit comparisons among groups. Data from replicate tanks did not differ significantly (ANOVA) with regard to fish length or change in the intensity of papillomatosis and so were combined before final analyses. Numbers of fish used in the statistical analyses are given in Table 1.

The effects of the treatments on the development of papillomatosis were analyzed using analysis of covariance (ANCOVA) with the change in the intensity of papillomatosis during the experiment as a response variable, treatment as a fixed factor and both fish length and intensity of papillomatosis at the beginning of the experiment as covariates. We tested the hypothesis that the development of papillomatosis would be highest in the OT group fish, less so in the T group fish and lowest in the control group fish by custom hypothesis test as polynomial contrast. Differences in the physiological indices, haematocrit and condition fac-

Table 1. Rutilus rutilus. Mortality (percentage of treatment group), mean $\pm \mathrm{SE}$ (n) for initial and final weight in male and female roach. Induction of papillomas (percentage of fish showing an increase in disease intensity in the treatment group), mean $\pm \mathrm{SE}(\mathrm{n})$ change in the intensity of papillomatosis (number of scales covered by papillomas), condition factor $(K)$, gonadosomatic index (GSI), and haematocrit $(\%)$ in male roach from different treatment groups. OT: periodic hypoxia, temperature increases and standing water. T: normoxia, but periodic temperature increases and standing water. C: constant low temperature, water flow and normoxic conditions. Different superscript letters indicate statistically significant differences $(p<0.05)$ between the treatment groups

\begin{tabular}{|lccc|}
\hline Treatment & OT & $\mathrm{T}$ & Control \\
\hline Mortality (\%) & $28^{\mathrm{a}}(8 / 29)$ & $0^{\mathrm{b}}(0 / 30)$ & $3^{\mathrm{b}}(1 / 30)$ \\
Initial weight (g) & $35.1 \pm 2.6(29)$ & $33.6 \pm 1.9(30)$ & $29.4 \pm 1.5(30)$ \\
Final weight (g) & $33.9 \pm 3.4(21)$ & $33.1 \pm 1.9(30)$ & $28.5 \pm 1.5(29)$ \\
Papilloma induction $(\%)$ & $100(19 / 19)$ & $84(21 / 25)$ & $44(12 / 27)$ \\
Papilloma intensity & $29.3 \pm 6.2^{\mathrm{a}}(19)$ & $19.5 \pm 6.1^{\mathrm{b}}(25)$ & $2.1 \pm 1.1^{\mathrm{c}}(27)$ \\
$\quad$ change & & & \\
$K$ & $0.93 \pm 0.02^{\mathrm{a}}(19)$ & $0.99 \pm 0.01^{\mathrm{b}}(25)$ & $1.00 \pm 0.02^{\mathrm{b}}(27)$ \\
GSI & $7.04 \pm 0.23^{\mathrm{a}}(19)$ & $7.22 \pm 0.23^{\mathrm{a}}(25)$ & $7.96 \pm 0.21^{\mathrm{a}}(27)$ \\
Haematocrit $(\%)$ & $36.39 \pm 1.23^{\mathrm{a}}(18)$ & $38.08 \pm 1.31^{\mathrm{a}}(25)$ & $35.54 \pm 1.25^{\mathrm{a}}(24)$ \\
\hline
\end{tabular}


tor, between the treatment groups were determined using ANOVA, followed by Bonferroni pairwise comparisons. We found a correlation between GSI and fish length in our study. For this reason the GSI was tested between groups by ANCOVA, where GSI was a response variable, treatment a fixed factor and length a covariate, so that the effect of length on GSI could be controlled. The following transformations were made to meet the assumptions of ANOVA and ANCOVA analyses: lg (intensity change +6 ), lg (papillomatosis intensity at the beginning) and lg (length). Statistical tests were performed using SPSS for Windows 13.0 (SPSS).

\section{RESULTS}

On Day 3, during the first exposure period, fish in the OT groups started to show behavioral signs of oxygen deficiency; fish were swimming near the water surface and respiratory intensity increased. When dissolved oxygen decreased to $0.3-0.8 \mathrm{mg} \mathrm{l}^{-1}$ on Day 4 (Fig. 1), a flight reaction from direct light was not observed in the fish and some fish lost their equilibrium. Such behavior was not observed in the $\mathrm{T}$ or control groups.

Eight fish died during the experiment in the OT group, while all fish survived in the $\mathrm{T}$ group, and 1 fish died in the control group (Table 1). The differences in the mortality were significant between the OT and $\mathrm{T}$ groups $\left(\chi^{2}=9.57, \mathrm{df}=1, \mathrm{p}=0.002\right)$ and between the OT and control groups $\left(\chi^{2}=6.71, \mathrm{df}=1, \mathrm{p}=0.010\right)$, but not between $\mathrm{T}$ and control group $\left(\chi^{2}=1.02, \mathrm{df}=1, \mathrm{p}=0.313\right)$ (Table 1$)$.

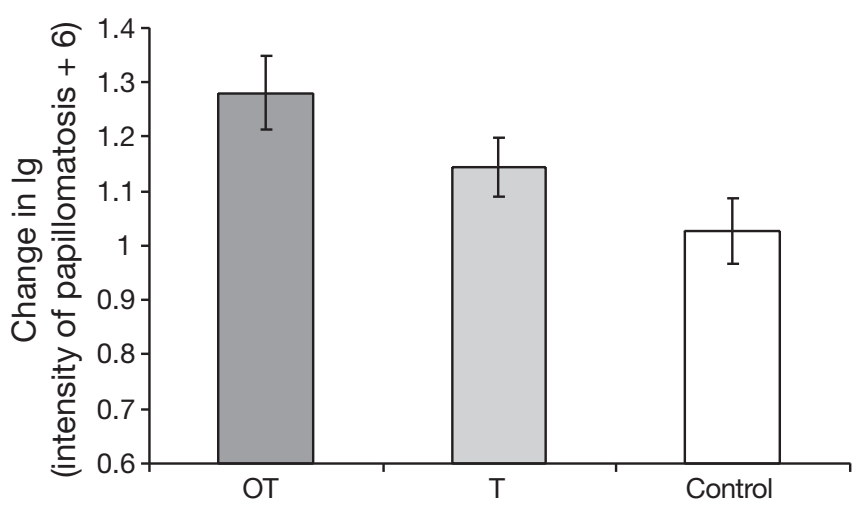

Fig. 2. Rutilus rutilus. Mean $( \pm \mathrm{SE})$ change in the intensity of papillomatosis, corrected for variation in length and disease intensity at the beginning of the experiment in male roach in different treatment groups. Means are given for covariate values for length $(\mathrm{lg})=1.175$ and papillomatosis intensity at the beginning $(\mathrm{lg})=1.031$. The linear trend in the change of papillomatosis intensity from OT to $\mathrm{T}$ to control group was statistically significant (polynomial contrast, $\mathrm{p}=0.013$ ). OT: elevated water temperature and low oxygen; $\mathrm{T}$ : normoxic, elevated water temperature (see Table 1 for a complete description of treatments)
Both papillomatosis induction (percentage of fish showing an increase in disease intensity) and the mean change in the intensity of the disease were highest in OT group and lowest in control group (Table 1). The ANCOVA model including factor by covariate interaction revealed that the interactions between 'treatment $\times$ length' and 'treatment $\times$ papilloma intensity at the beginning' were not significantly different $\left(F_{2,71}=\right.$ 0.680, $\mathrm{p}=0.510$ and $F_{2,71}=0.716, \mathrm{p}=0.493$, respectively). This indicated that the effects of the covariates, length and intensity of papillomatosis at the beginning of the experiment, did not differ between the treatments. Therefore, ANCOVA was continued with the full factorial model where length $\left(F_{1,71}=6.375, \mathrm{p}=\right.$ $0.014)$ and disease intensity at the beginning $\left(F_{1,71}=\right.$ $25.102, \mathrm{p}<0.001$ ) had significant effects on the change of papillomatosis intensity during the experiment. Both covariates affected the change of the intensity of papillomatosis positively. There was a statistically significant difference in the change of papillomatosis intensity between the treatment groups ('treatment': $F_{2,71}=$ 3.296, $\mathrm{p}=0.043$ ). Polynomial contrast revealed that there was a statistically significant linear trend in the change of papillomatosis intensity from OT to T to control group ( $p=0.013$ ) (Fig. 2). Thus, in accordance with our hypothesis, the OT group fish expressed highest, the $\mathrm{T}$ group the second highest, and the control group lowest increase in the intensity of papillomatosis during the experiment (Fig. 2).

The mean length-adjusted GSI was lowest in the OT group and highest in the control group, but the differences between groups were not significantly different (ANCOVA: $F_{2,71}=2.021, \mathrm{p}=0.141$ ) (Table 1 ). The condition factor in the OT group was significantly lower than in the $\mathrm{T}$ group (Bonferroni pairwise comparison, $\mathrm{p}=0.035$ ) and the control group (Bonferroni pairwise comparison, $\mathrm{p}=0.005)$, but there was no statistically significant difference between the $\mathrm{T}$ and control groups in condition factor (Bonferroni pairwise comparison, $\mathrm{p}=1.000$ ) (Table 1). Differences between the treatment groups in haematocrit were not significant (Table 1).

\section{DISCUSSION}

Our hypothesis was that hypoxia would increase the intensity of epidermal papillomatosis in roach. More specifically, we hypothesized that the increase of the disease intensity would be highest in fish exposed to periodic hypoxia, periodic temperature increases and periodic standing water (OT group), second highest in fish exposed to periodic temperature increase and periodic standing water ( $\mathrm{T}$ group) and lowest in fish kept in constant low temperature and normoxia (con- 
trol group). Our results support this hypothesis. In accordance with our results, papilloma prevalence peaked after oxygen depletion in the North Sea dab along the coast of Denmark (Mellergaard \& Nielsen 1995, 1997), indicating a possible connection between low oxygen and the papilloma disease in this fieldbased study. Low oxygen is a serious environmental stressor for aquatic ecosystems that include feral fish (Wu 2002). Recent studies indicate that hypoxia can, for instance, cause embryonic malformation and impair reproduction and larval development in fish (Wu et al. 2003, Shang \& Wu 2004, Ishibashi et al. 2005). Hypoxia also enhances the developmental rate and virulence of pathogens. Low oxygen concentration increased bacterial loads in experimentally infected channel catfish Ictalurus punctatus (Walters \& Plumb 1980, Mqolomba \& Plumb 1992). In addition, exposure to hypoxia increased mortality of diseased fish (Caldwell \& Hinshaw 1995, Fukuda et al. 1997, Fisk et al. 2002). Studies on aquatic invertebrates have shown severe and long-lasting effects of hypoxia on susceptibility to bacterial and parasitic infections (e.g. Cheng et al. 2002, Saarinen \& Taskinen 2005). The present results suggest that hypoxia can also contribute to the development of the tumor-inducing viral disease, papillomatosis, in fish.

In addition to low oxygen, our results indicate that temperature may be one of the multifactorial elements that have an effect on papillomatosis in roach. In the present experiment, roach were exposed a fluctuating temperature between 1 and $10^{\circ} \mathrm{C}$ in both the OT and $\mathrm{T}$ groups. Our result indicates that a fluctuating water temperature like this might have an effect on induction of papillomas in roach. Temperature has been demonstrated to have an effect on several fish diseases. Temperature affects the function of the poikilothermic fish immune system and the virulence of many pathogens is dependent on ambient temperature (Le Morvan et al. 1998, Slater \& Schreck 1998). Seasonal changes with accompanying fluctuating water temperature have been noticed for many virally induced skin tumors, such as papillomatosis (Getchell et al. 1998). However, the observed seasonality in fish papillomatosis might be explained also by seasonal changes in endocrine activity that occur during the period of seasonal changes in water temperature (Anders \& Yoshimizu 1994). However, the previous results on the association between water temperature and development of papillomatosis are not consistent. Exposure to elevated temperatures $\left(15\right.$ to $22^{\circ} \mathrm{C}$ ) increased, while low temperatures $\left(5\right.$ to $16^{\circ} \mathrm{C}$ ) inhibited growth of papillomas in eels Anguilla anguilla in an $8 \mathrm{wk}$ experiment (Peters 1977). In contrast, optimal temperature for replication in vitro for papilloma-inducing virus herpesvirus cyprini was 15 to $20^{\circ} \mathrm{C}$, but papillomatosis regressed in temperatures above $20^{\circ} \mathrm{C}$ in vivo probably because the immunity of the carp to the virus infection depends on the ambient temperature (Sano et al. 1993).

In addition to hypoxia and elevated temperature, the fish in OT and $\mathrm{T}$ groups were subjected to periodic standing water, which may have an effect on water quality by increasing levels of carbon dioxide and ammonia, which in turn can lead to blood plasma acidosis of fish during stress (Paterson et al. 2003). Therefore, we cannot rule out that the increase in disease intensity in the treatment groups was further affected by the standing water conditions. To reduce the possible effect of standing water, the water was changed during the first exposure period so that the maximum duration of standing water conditions during the experiment was $3 \mathrm{~d}$. More importantly, standing water cannot explain the main result of the present study - the effect of oxygen deficiency - since the OT and T groups both experienced similar standing water quality conditions.

Papillomatosis did not affect the survival of adult roach in a natural cage experiment (Kortet et al. 2003c). Thus, in the present experiment the higher mortality and the specific behavioral signs, such as swimming near the water surface, increased respiratory intensity and loss of equilibrium, indicate severe stress in the OT group (Baroudy \& Elliott 1994). Another indicator of severe stress was the significantly lower condition factor in the OT group. Condition factor is usually considered to indicate fitness of fish, and during stress fish experience physiological changes to maintain homeostasis (Wendelaar Bonga 1997), which can further reduce overall fitness. Moreover, hypoxia can reduce the specific growth rate and RNA:DNA ratio, which are important indicators of fitness, in white muscle of carp Cyprinus carpio (Zhou et al. 2001). Lower condition factor in this experiment was partly contributed by lower mean GSI in the stressed fish, although the difference between treatments groups in GSI were not statistically significant. Our experiment was done in early spring, during the final maturation of roach, when consequences of stressors to reproduction of fish are dependent on the stage of reproductive development (Donaldson 1990). It is probable that under severe hypoxic stress the final maturation of fish is interrupted or slowed down; evidently, gonads of roach in the OT group did not develop in comparison with gonads of roach in the control group. Alternatively, stress may have disrupted the hormonal balance of the fish in the present experiment. Wu et al. (2003) found decreased serum levels of steroids and retarded gonadal development after chronic exposure to hypoxia in carp. Papillomatosis is associated with high concentrations of circulating testosterone in male roach (Kortet et al. 2003a) and hormonal manipulations 
affect the development of papillomatosis on fish (Premdas et al. 2001); hence, the development of papillomatosis in this experiment must be more of a consequence of stress than of hormones.

Increased intensity of papillomatosis during the experiment was affected by fish length and initial papillomatosis intensity, as well as oxygen deficiency and fluctuating temperature. Therefore, it was important to be able to control the effects of these variables by using them as covariates in ANCOVA. They affected positively the development of papillomatosis in all treatments, as indicated by the insignificant factor by covariate interactions. It seems that papillomas in feral fish are constantly regressing or proliferating (Premdas \& Metcalfe 1994, Getchell et al. 1998). High initial disease intensity may mean multiple foci of tumors proliferate, or regress. If stress does promote tumor growth, it is reasonable to assume that the promoting effect is proportional to the number and size of existing tumors.

Epidermal papillomatosis of roach has been suggested as a biomarker for environmental stress since its prevalence was higher in polluted lakes (Kortet et al. 2002) and in polluted areas within lakes in a matched-pairs field study (Korkea-aho et al. 2006a). The advantages of using a roach-papillomatosis system include the abundance and wide distribution of roach in Europe. In addition, roach are easy to catch and examine for papillomatosis and the disease does not effect the survival of adult roach (Kortet et al. 2003c). In the present study, we demonstrated a specific cause-and-effect relationship between oxygen deficiency and the development of papillomatosis in roach. This increases the usefulness of the roachpapillomatosis system as an indicator of environmental stressors. Furthermore, this contributes to our understanding of hypoxia's effects on fish and encourages further research on the effect of hypoxia on disease susceptibility in natural fish populations.

Acknowledgements. The research was funded by the Maj and Tor Nessling Foundation (T.L.K. and J.M.P.) and the Olvi Foundation (J.M.P.). We thank the personnel in the Fisheries Research Unit of the University of Kuopio for assistance in collection and examination of the fish and H. Simola for helpful comments on the manuscript.

\section{LITERATURE CITED}

Anders K, Yoshimizu M (1994) Role of viruses in the induction of skin tumours and tumour-like proliferations of fish. Dis Aquat Org 19:215-232

Barcellos LJG, Nicolaiewsky S, de Souza SMG, Lulhier F (1999) The effects of stocking density and social interaction on acute stress response in Nile tilapia Oreochromis niloticus (L.) fingerlings. Aquac Res 30:887-892
Baroudy E, Elliott JM (1994) Tolerance of parr of arctic charr, Salvelinus alpinus, to reduced dissolved oxygen concentrations. J Fish Biol 44:736-738

Baumann PC, Smith IR, Metcalfe CD (1996) Linkages between chemical contaminants and tumors in benthic Great Lakes fish. J Gt Lakes Res 22:131-152

Bolger T, Connolly PL (1989) The selection of suitable indices for the measurement and analysis of fish condition. J Fish Biol 34:171-182

Caldwell CA, Hinshaw JM (1995) Tolerance of rainbow trout to dissolved oxygen supplementation and a Yersinia ruckeri challenge. J Aquat Anim Health 7:168-171

Cheng W, Liu C, Hsu J, Chen J (2002) Effect of hypoxia on the immune response of giant freshwater prawn Macrobrachium rosenbergii and its susceptibility to pathogen Enterococcus. Fish Shellfish Immunol 13:351-365

Diaz RJ, Rosenberg R (1995) Marine benthic hypoxia: a review of its ecological effects and the behavioural responses of benthic macrofauna. Oceanogr Mar Biol Annu Rev 33:245-303

Donaldson EM (1990) Reproductive indices as measures of the effects of environmental stressors in fish. In: Adams SM (ed) Biological indicators of stress in fish. American Fisheries Symposium 8, Bethesda, MD, p 109-122

Fisk DM, Powell MD, Nowak BF (2002) The effect of amoebic gill disease and hypoxia on survival and metabolic rate of Atlantic salmon (Salmo salar). Bull Eur Assoc Fish Pathol 22:190-194

Fukuda Y, Maita M, Satoh KI, Okamoto N (1997) Influence of dissolved oxygen concentration on the mortality of yellowtail experimentally infected with Enterococcus seriolicida. Fish Pathol 32:129-130

Getchell RG, Casey JW, Bowser PR (1998) Seasonal occurrence of virally induced skin tumors in wild fish. J Aquat Anim Health 10:191-201

Ishibashi Y, Inoue K, Nakatsukasa H, Ishitani Y, Miyashita S, Murata O (2005) Ontogeny of tolerance to hypoxia and oxygen consumption of larval and juvenile red sea bream, Pagrus major. Aquaculture 244:331-340

Kestemont P, Rinchard J, Feys V, Fostier A (1999) Spawning migrations, sexual maturity and sex steroid levels in female roach Rutilus rutilus from the River Meuse. Aquat Sci 61:111-121

Korkea-aho TL, Partanen JM, Kiviniemi V, Vainikka A, Taskinen J (2006a) Association between environmental stress and epidermal papillomatosis of roach Rutilus rutilus. Dis Aquat Org 72:1-8

Korkea-aho T, Vainikka A, Taskinen J (2006b) Factors affecting the intensity of epidermal papillomatosis in populations of roach, Rutilus rutilus (L.), estimated as scale coverage. J Fish Dis 29:115-122

Kortet R, Vainikka A, Taskinen J (2002) Epizootic cutaneous papillomatosis in roach Rutilus rutilus: sex and size dependence, seasonal occurrence and between-population differences. Dis Aquat Org 52:185-190

Kortet R, Taskinen J, Sinisalo T, Jokinen I (2003a) Breedingrelated seasonal changes in immunocompetence, health state and condition of the cyprinid fish, Rutilus rutilus, L. Biol J Linn Soc 78:117-127

Kortet R, Vainikka A, Rantala MJ, Jokinen I, Taskinen J (2003b) Sexual ornamentation, androgens and papillomatosis in male roach (Rutilus rutilus). Evol Ecol Res 5:411-419

Kortet R, Vainikka A, Taskinen J (2003c) Effect of epidermal papillomatosis on survival of the freshwater fish Rutilus rutilus. Dis Aquat Org 57:163-165

Kortet R, Taskinen J, Vainikka A, Ylönen H (2004) Breeding 
tubercles, papillomatosis and dominance behaviour of male roach (Rutilus rutilus) during the spawning period. Ethology 110:591-601

Lee S, Whitfield PJ (1992) Virus-associated spawning papillomatosis in smelt, Osmerus eperlanus L., in the River Thames. J Fish Biol 40:503-510

Lehtonen H, Rask M (2004) Fishes and fisheries. In: Eloranta $\mathrm{P}$ (ed) Inland and coastal waters of Finland. Palmenia Publishing, Helsinki, p 84-92

Le Morvan C, Troutaud D, Deschaux P (1998) Differential effects of temperature on specific and nonspecific immune defences in fish. J Exp Biol 201:165-168

Mallin MA, Johnson VL, Ensign SH, MacPherson TA (2006) Factors contributing to hypoxia in rivers, lakes, and streams. Limnol Oceanogr 51:690-701

Mellergaard S, Nielsen E (1995) Impact of oxygen deficiency on the disease status of common dab Limanda limanda. Dis Aquat Org 22:101-114

Mellergaard S, Nielsen E (1997) Epidemiology of lymphocystis, epidermal papilloma and skin ulcers in common dab Limanda limanda along the west coast of Denmark. Dis Aquat Org 30:151-163

Mqolomba TN, Plumb JA (1992) Effect of temperature and dissolved oxygen concentration on Edwardsiella ictaluri in experimentally infected channel catfish. J Aquat Anim Health 4:215-217

Paterson BD, Rimmer MA, Meikle GM, Semmens GL (2003) Physiological responses of the Asian sea bass, Lates calcarifer, to water quality deterioration during simulated live transport: acidosis, red-cell swelling, and levels of ions and ammonia in the plasma. Aquaculture 218:717-728

Peters G (1977) The papillomatosis of the European eel (Anguilla anguilla L.): analysis of seasonal fluctuations in the tumor incidence. Arch Fischwiss 27:251-263

Peters G, Peters N (1979) The influence of salinity on growth and structure of epidermal papillomas of the European eel Anguilla anguilla L. J Fish Dis 2:13-26

Pickering AD (1986) Changes in blood cell composition of the brown trout, Salmo trutta L., during the spawning season. J Fish Biol 29:335-347

Premdas PD, Metcalfe CD (1994) Regression, proliferation and development of lip papillomas in wild white suckers, Catostomus commersoni, held in the laboratory. Environ Biol Fishes 40:263-269

Premdas PD, Metcalfe TL, Bailey ME, Metcalfe CD (1995) The prevalence and histological appearance of lip papillomas in white suckers (Catostomus commersoni) from two sites in central Ontario, Canada. J Gt Lakes Res 21:207-218

Editorial responsibility: Carl Schreck, Corvallis, Oregon, USA
Premdas PD, Metcalfe CD, Brown S (2001) The effects of 17 $\beta$-oestradiol, testosterone and tamoxifen on the development of papillomata in Catostomus commersoni. J Fish Biol 59:1056?1069

Saarinen M, Taskinen J (2005) Long-lasting effect of stress on susceptibility of a freshwater clam to copepod parasitism. Parasitology 130:523-529

Sano N, Moriwake M, Sano T (1993) Herpesvirus cyprini: thermal effects on pathogenicity and oncogenicity. Fish Pathol 28:171-175

Shang EHH, Wu RSS (2004) Aquatic hypoxia is a teratogen and affects fish embryonic development. Environ Sci Technol 38:4763-4767

Slater CH, Schreck CB (1998) Season and physiological parameters modulate salmonid leucocyte androgen receptor affinity and abundance. Fish Shellfish Immunol 8:379-391

Vainikka A, Kortet R, Taskinen J (2004a) Epizootic cutaneous papillomatosis, cortisol and male ornamentation during and after breeding in the roach Rutilus rutilus. Dis Aquat Org 60:189-195

Vainikka A, Jokinen EI, Kortet R, Taskinen J (2004b) Genderand season-dependent relationships between testosterone, oestradiol and immune functions in wild roach. J Fish Biol 64:227-240

Vethaak AD, Bucke D, Lang T, Wester PW, Jol J, Carr M (1992) Fish disease monitoring along a pollution transect: a case study using dab Limanda limanda in the German Bight. Mar Ecol Prog Ser 91:173-192

Walters GR, Plumb JA (1980) Environmental stress and bacterial infection in channel catfish, Ictalurus punctatus Rafinesque. J Fish Biol 17:177-185

Watanuki H, Yamaguchi T, Sakai M (2002) Suppression in function of phagocytic cells in common carp Cyprinus carpio L. injected with estradiol, progesterone or 11ketotestosterone. Comp Biochem Physiol C 132:407-413

Wedekind C (1996) Lek-like spawning behaviour and different female mate preferences in roach (Rutilus rutilus). Behaviour 133:681-695

Wendelaar Bonga SE (1997) The stress response in fish. Physiol Rev 77:591-625

Wu RSS (2002) Hypoxia: from molecular responses to ecosystem responses. Mar Pollut Bull 45:35-45

Wu RSS, Zhou BS, Randall DJ, Woo NYS, Lam PKS (2003) Aquatic hypoxia is an endocrine disruptor and impairs fish reproduction. Environ Sci Technol 37:1137-1141

Zhou BS, Wu RS, Randall DJ, Lam PK (2001) Bioenergetics and RNA/DNA ratios in the common carp (Cyprinus carpio) under hypoxia. J Comp Physiol B 171:49-57

Submitted: June 15, 2007; Accepted: October 26, 2007

Proofs received from author(s): January 14, 2008 